\title{
The Business Vision and Mission
}

\author{
Ph.D. Branislav Djordjevic** \\ Emeritus \\ *Corresponding Authors: Ph.D. Branislav Djordjevic, Emeritus \\ That business missionis so rarely given adequate thought is perhaps the most important saingle cause \\ of business frustration.
}

\section{PeTER Drucker}

We can perhaps best understand vision and mission by focusing on a business wh- en it is first started. In the beginning, a new business is simply a collection of ideas. Starting a new business rests on a set of beliefs that the new organization can offer some product or services to some customers, in some geographic area, using some type of tech- nology, at a profitable price. A new business owner typicaslly believes that the manage-ment philosophy of the new enterprise will result in a favourable public image and that this concept of the business can be communicated to, and will be adopted by, important constituencies. When the set of beliefs about a business at its inception is put into writing, the resulting document mirrors the same basic ideas that underlie the vision and mission statements. As a business grows, owners or managemers find it necessary to revise the fo- unding set of beliefs, but those original ideas usually are reflected in the revised stateme- nts of vision and mission.

Vision and mission statements often can be found in the front of annual reports. They often are displayed throuhgout a firm's premises and are distributed with company information sent to constituencies. The statements are part of numerous internal reports, suchas loan requests, supplier agreements, labor relations contracts, business plans, and customer service agreements. In a recent study, researchers concluded that 90 percent of all companiesd have used a nission statement sometime in the previous five yeras. ${ }^{1}$

\section{What Do We WANT To BECOME?}

It is especially important for managers and executives in any organization to agree upon the basic vision that the firm stgrives to achieve in the long term. A vison statement should answer the basic question. "What do we want to become?" A clear vision provides the foundation for developing a comprehensive mission statement. Many organizations have both a vision and $\mathrm{n}$ ission statement, but the vision should be established first and foremost. The viusion statement should be short, prefereably one sentence, and as many managers as possible should have input into developing the statement.

\section{WHAT IS OUR BUSINESS?}

Current throught on mission statements is based largely on guidelines set forth in the mid-1970s by Peter Drucker, who is often called "the father of modern management" for his pioneering studies at general Motors Corporation and for his 22 books and hundre- ds of articles. Drucker has been called "the preeminent management thinker of our time."

Drucker says that asking the question "What is our business?" is synonymous wi- th asking the question "What is our mission?" An enduring statement of purpose that dist- inguishes one organization from other similar enterprise, the mission statement is a decle- ration of an organizatioin's "reason for being". It answers the pivotal question "What is our business?" A clear mission statement is essential for establioshing objectives and for- mulating strategies.

\footnotetext{
${ }^{1}$ Barbara Barkus, Myron Glassman, and Bruce McAfee, "Mission Statements: Are They Smoke and Mirrors"? Businesss Horizons (November-December 2000); 23
} 
Sometimes called a creed statement, a statement of philosophy, a statement of be- liefs, a statement of business principles, or a statement "defining our business," a mission statement reveals what an organization wants to be and whom it wants to serve. All orga- nizations have a reason for being, even if strategists have not consciously transformed th- is reason into writing. As illustrated in Figure 2-1, carefully prepared statements of vision and mission are widely recognized by both practitioners and academicians as the first step in strategic management.

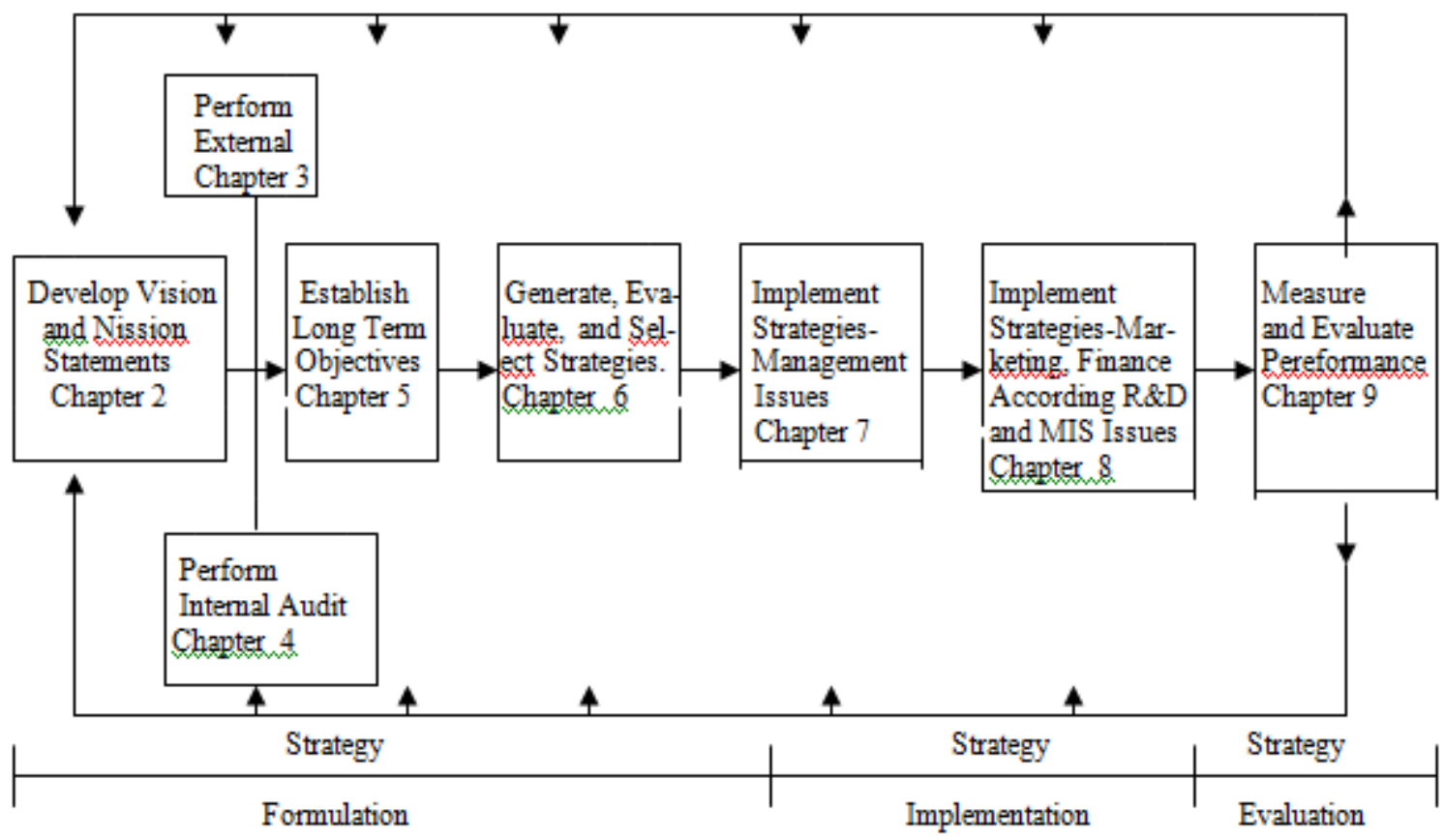

Figure2.1. A Comprehensive Strategic-Management Model

Source: Fred R. David, “How Companies Define Their Mission," Long Range Planning 22, no. 3 (June 1988): 40

A business mission is the foundation for priorities, strategies, plans, and work as- signments. It is the starting point for the design of managerial jobs and, above all, for the design of managerial structures. Nothing may seem simpler or more obvious than to kn- ow what a company's business is. A steel mill makes steel, a railroad runs traims to carry freight and passengers, an insurence company underwrites fire risks, and a bank lends money. Actually, "What is our business?" is almost always a difficult question and the right answer is usually anything but obvious. The answer to this question is the first responsibility of strategies. Only stategists can make sure that this wuestion receives the attention it deserves and that the answer makes sense and enables the busieness to plot its course and set its objectives. ${ }^{2}$

Some strategies spend almost every moment of every day on administrateive and tactical concerns, and strategists who rush quickly to establish objectives and implement startegies often overlook the development of a vision and mission statement. This probl- em is widespread even among large organizations. Many corporations in America have not yet developed a formal vision or mission statement. ${ }^{3}$ An increasing number of organi- zations are developing these statements.

Some companies develop mission statements simly because they feel it is fashio- nable, rather than out of any real commitment. However, as will be described in this cha- pter, firms that develop and systematically revisit their vision and mission statements, tre- at them as living documents, and consider them to be an integral part of the firm's cult- ure realize great benefits. Jonson \& Jonson $(\mathrm{J} \& \mathrm{~J})$, the maker of medical-related products, is an example firm. J\&J managers meet regularly with employees to review, reword, and reaffirm the firm's vision and mission. The entire J\&J workforce

2 Peter Drucker, Management: Tasks, responsibilities, and Practices (New York: Harper \&Row, 1974): 61.

3 Fred David,"How Companies Define Their Mission,"Long Range Planning 22, no. 1.

(February 1989): 90-92; John Pearce II and Fred David,“'Corporate Mission Statements: The Bottom Line,” Academy of Management Executive 1, no. 2 (May 1987): 110. 
recognized the value th- at management places on this exercises, and these employees respodnd accordingly.

\section{VISION VERSUS MISSION}

Many organizations develop both a mission statement and a vision statement. Whereas the mission statement answers the question "What is our business," the vision statement answers the question" What do we want to become?" Many organizations have both a mi- ssion anmd vision statement.

It can be agrued that profit, not mission or vision, is the primary corporate motiva- tor. But profit alone is not enough to motivate people. ${ }^{4}$ Profit is perceived negatively by some employees in companies. Employees may see profit as something that they earn and management then uses and even gives away to shareholders. Although this percepti- on is undesired and disturbing to management, it cleraly indicates that both profit and vis- ion are needed to effectively motivate a workforce.

When employees and managers together or fashion the vision and mission statem- ents for a firm, the resultant documents can reflect the personal visions that managers and employees have in their heart and minds about their own futures. Shared vision creates a commonality or interests that can lift workers out of the monotony of daily work and put them into a new world of opportunity and challenge.

\section{THE PROCESS OF DEVELOPING VISION AND MisSiON STATEMENTS}

As indicated in the strategic-management model, clear vision and mission statements are

needed before alternative strategies can be formulated and implemented. It is important to involve as many managers as possible in the process of developing these statements, bec- ause through involvement, people become committed to an organization.

A widely used approach to developing a vision and mission statement is first to select several articles about these statements and ask all managers to read these as backg- round information. Then ask managers themselves to prepare a vison and mission statem- ent for the organization. A facilitator, or committee of top managers, should then merge these statements into a single document and distribute the draft statements to all manage- rs. A request for modifications, addition, and deletions is needed next, along with a meet- ing to revise the document. To the extent that all managers have input into and support the final documents, organizations can more easily obtain managers' support for other strategy formulation, implementation, and evaluation activities.Thus, the process of devel- oping a vision and mission statement represents a great opportunity for strategists to obtain needed support from all managers in the firm.

During the process of developing vision and mission statements, some organizati- ons use discussion groups of managers to develop and modify existing statements. Some organizations hire an outside consultatnt or facilitator to manage the process and help dr- aft the language. Sometimes an outside person with expertise in developing such statem- ents, who has unbiased view, can manage the process more effectively than an internal group or committee of managers. Decisions on how best to communicate the vision and mission to all managers, employees, and external constituencies of an organization are needed when the documents, and how they were developed.

An article by Campbell and Yeng emhasizes that the process of developing a mission statement should create an "emotional bond" and "sense of mission" between the organization and its employees. ${ }^{5}$ Commitment to a company's strategy and intellectual agreement on the strategies to be pursued do not necessarily translate into an emotional bond; hence, strategies that have been formulated may not be implemented. These resea- rches stress that an emotional bond comes when an indivisdual personally identifies with the underlying values and behavior of a firm, thus turning intellectual agreement and co- mmitment to strategy into a sense of mission. Campbell and Yeung

\footnotetext{
4 Joseph Quigley, “Vision: How Leaders Develop It, Share It and Sustain It,'Business Horizons (September-October 1994): 39.

5 Andrew Campbell and Sally Yeung, "Creating a Sense of Mission," Long Range Planning 24, no. 4. (August 1991): 17.
} 
also differentiate bet- ween the term vision and mission, saying that vision is "a possible and desirable future state of an organization" that includes specific goals, whereas mission is more associated with behavior and the present.

\section{IMPORTANCE (BENEFITS) OF VISIONB AND MISSION STATEMENTS}

The importance (benefits) of vision and mission statements to effective strategic management is well documented in the literature, although research are mixed. Rarick and Vitton found that firms a formalized mission statement have twice the average return on shareholders' equity than those firms without a formalized mission statement have;Ba- rt and Beatz fount a positive relationship between mission statements and organizational performance; Business Week magazine reports that firms using mission statements have a 30 percent higher return on certain financial measures than those without such statemen- ts; however, some studies have found that having a mission statements does not directly contribute positively to finacial performance. ${ }^{6}$ The extent of manager and employee involvement in developing vision and nmission statements can make a difference in business success. This chapter $\mathrm{p}$ [rovides guidelines for developing these important documents. In actual practice, wide variations exict in the nature, composition, and use of both vision and mission statements. King and Clelenad recommended that organizations carefully develop a written mission statement in order to keep the following benefits:

1. To ensure unanimaty of purpose within the organization

2. To provide a basis, or standard, for allocating organizational resources

3. To establish a general tone or organizational climate

4. To serve as a focal point for individuals to identify with the organization's purpo- se and direction, and to deter those who cannot from participating further in the organization's activities

5. To faciliate the translation of objectives into a work structure involving the assig- ment of tasks to responsible elements within the organization

6. To specify organizational purposes and then to translate these purposes into obje-ctives in such a way that cost, time, and performance parameters can be assessed and controlled.

Reuben Mark, former CEO of Colgate, maintains that a clear mission increasingly must make sense internationally. Mark's thoughts on vision are as follows:

When it comes to reallying everyone to the corporate banner, it's essential to push one vision globally rather than trying to drive home different messages in different cultures. The trick is to keep the vision simple but elevated: "We make the world's fastest computers" or "Telephone service for everyone." You're never going to get anyone to change the machine guns only financial objectives. It's got to be something that makes people feel better, feel a part of something. ${ }^{8}$

\section{Characteristics of a Mission Statement}

\subsection{A Decleration of Attitude}

A mission statement is more han a statement of specific details; it is a declaration of attitude and outlook. It usually is broad in scope for at least two major reasons. First, a good mission statement allows for the generation and consideration of a range of feasible alternative objectives and strategies without unduly stifling management creativity. Exc- ess specificity would limit the potential of creative growth for the organization. On the other hand, an overly general statement that does not exclude any strategy alternatives could be dysfunctional.

Lenovo Computer's mission statement, for example, should not open the possibility for diversification into pesticides-or Volkswagen's into food processing.

6 Charles Rarick and John Vitton, “Mission Statements Make Cents, ” Journal of Business Strategy 16 (1995); 11, Also, Cristoipher Bart and Mark Baetz, "The Relationship Between Mission Statements and Firm Performance: An Exploratory Study, “, Journal of Management Studies 35 (1998); 823; ”Mission Possible,” Business Week (August 1999); F12.

7 W.R. King and D.I. Cleland, Strategic Planning and Policy (New York: Van Nostrand Reinhold, 1979); 124.

8 Brian Dumaine, “What the Leaders of tomorrow See,” Fortune (July 3, 1989): 50. 
Second, a mission statement needs to be broad to effectively reconcile differences among, and appeal to, an organization's diverse stakeholders, the individuals and groups of individuals who have a special stake or claim on the company. Stakeholders include employees, managers, stockholders, boards of directors, customers, suppliers, distributo- rs, creditors, goverments (local, state, federal, and foreign), unions, competitors, enviro- nmental groups, and geberal public. Stakeholders affect and are affected by an organizat- ion's strategies, yet the claim and concerns of diverse constituencies vary and often conf- lict. For example, the general public is especially interested in social responsibility, whe- reas stockholders are more interested in profitability. Claims on any business literally may number in the thousands, and they often include clean air, jobs, taxes, investment opportunities, career opportunities, erqual employment opportunities, employee benefits, salaries, wages, clean water, and community services. All stakeholders' claim on an orga- nization cannot be pursued with equal emphasis. A good mission statement indicates the relative attention that an organziation will devote to meeting the claims of various stake- holders. Many firms are environmentally proactive in respnse to the concerns of stakehol- ders, as indicated in the "Natural Environment Perspective" box.

The fine balance between sxpecificity and generality is fifficult to achieve, but it is well worth the effort. George Steiner offers the following insight on the need for a mission statement to be broad in scope:

Most business statements of mission are expressed at high levels of abstraction. Vagueness nevertheless has its virtues. Mission statements are not designed to express concrete ends, but rather to provide motivation, generala direction, an image, a tone, and a philosophy to guide the enterprise. $n$ excess of detail could prove counterproductive since concrete specification could be the base for rally-ing opposition. Precision might stifle creativity in the formulatyion of an acc-eptable mission or purpose. Once an aim is cast in concrete, it creates a rigidity in an organization and resist change. Vagueness leaves room for other manager-rs to fill in the details, perhaps even to modify general patterns. Vagueness per -mits more flexibility in adapting to changing environments and internal operati-ons. It facilitates flexibility in implementation. ${ }^{9}$

In additional to being broad in scope, an effective mission statement should not be too lenghthy; ecommended lenght is less than 250 words. An effective mission statement should arouse positive feelings and emotions about an organization; it should be inspiring in the sense that it motivates readers to action. A mission statement should be enduring. All of the above are desired characteristics of a statement. An effective mission stateme- nt generates the impressions taht a firm is successful, has direction, and is worthy of time, support, and investment - from all socioeconomic groups of people.

It reflect judgements about future growth directions and strategies that are based upon forwardlooking external and internal analyses. A business mission should provide useful criteria for selecting among alternative strategies. A clear mission statement provi-

des a basis for generating and screening strategic options. The statement of mission sho- uld be dynamic in orientation, allowing judgements about the most promising growth dir- ections and those considered less promising.

\section{Mission Statement COMPONENTS}

Mission statements can and do vary in lenght, content, format, and specificity. Most practitioners and academicians of stratyegic management feel that an effective stat- ement exhibits nine characteristics or components. Because a mission statement is often the most visible and public part of the strategicmanagement process, it is important that it includes all of these essential components:

1. Customers - Who are the firm's customers?

2. Products or services - What are the firm's major products or services?

3. Markets - Geographically, where does the firm compete?

9 George Steiner, "Strategic Planning: What Every Manager Must Know " (New York: The Free Press, 1979): 160. 
4. Technology - Is the firm tehnologiocally current?

5. Concern for survival, growth, and profitability - Is the firm committed to growth and financial soundness?

6. Philosophy - What are the basic beliefs, values, aspirations, and ethical prior-ities of the firm?

7. Self-concept - What is the firm's distinctive competence or major competitive advantage?

8. Concern for public image - Is the firm responsive to social, community, and environmental concerns?

9. Concern for employees - Are employees a valuable asset of the firm?

\subsection{Writing and Evaluating Mission Statements}

Perhaps the best way to develop a skill for writing and evaluating mission statem- ents is to study actual company missions. Therefore, the mission statements are evaluated based on nine desired components.

There is no one best mission statement for a particular organization, so good jud- gment is required in evaluating mission statements. Realize thaat some inividuals are mo- re demanding than others in assessing mission statements in this maner. For example, if a statement merely includes the world"customers" without specifying who the customers are, is that satisfactory? Ideallya statement would provide more than simply inclusion of a single word such as "products" or "employees" regarding a respective component. Why? Because the statement should be informative, inspiring, enduring, and serve to motivate stakeholders to action. Evaluating of a mission statement regarding inclusion of the nine components is just the beginning of the process to assess a statement's overall efectiven- es.

\section{CONCLuSion}

Every organization has a unique purose and reason for being. This uniqueness should be reflected in vision and mission statements. The nature of a business vision and mission can represent either a competitive advantage or disadvantage for the firm. An or-ganization achieves a hightened sense of purpose when strategists, managers, and emplo- yees develop and communicate a clear business visiuon and mission. Drucker says that developing a clear business vision and mission is the "first responsibility of strategists."

A good mission statement reveals an organization's customers; products or servic- es, market; technology; concern for survival, growth, and profitability; philosophy; self-concept; concern for publicimage; and concern for employees. These nine basic compon- ents serve as a practical framework for evaluating and writing mission statement. As the first step in strategic management, the vision and mission statements provide direction for all planning activities.

Well-designed vision and mission statements are essential for formulating, imple- menting, and evaluating startegy. Developing and communicaing a clear business vision and mission, are the most commonly overlooked tasks in strategic management. Without clear statements of vision and mission, a firm's short-term action can be counterproducti- ve to long-term interests. Vision and mission statements always should be subject to revis- ion, but, if carefully prepared, they will require infrequent major changes. Organizations usually reexamine their vision and mission statements anually. Effective mission stateme- nts stand the test of time.

\section{REFERENCES}

[1] Barbara Barkus, Myron Glassman, and Bruce McAfee, "Mission Statements: Are They Smoke and Mirrors"? Businesss Horizons (November-December 2000); 23

[2] Peter Drucker, Management: Tasks, responsibilities, and Practices (New York: Harper \&Row, 1974): 61.

[3] Fred David,"How Companies Define Their Mission,"Long Range Planning 22, no. 1. (February 1989): 9092; John Pearce II and Fred David,"Corporate Mission Statements: The Bottom Li-ne," Academy of Management Executive 1, no. 2 (May 1987): 110.

[4] Joseph Quigley, “Vision: How Leaders Develop It, Share It and Sustain It,"Business Horizons (September-October 1994): 39.

[5] Andrew Campbell and Sally Yeung, "Creating a Sense of Mission," Long Range Planning 24, no. 4. (August 1991): 17. 
[6] Charles Rarick and John Vitton, “Mission Statements Make Cents,” Journal of Business Strategy 16 (1995); 11, Also, Cristoipher Bart and Mark Baetz, "The Relationship Between Mission Statements and Firm Performance: An Exploratory Study, “, Journal of Management Studies 35 (1998); 823; "Mission Possible,” Business Week (August 1999); F12.

[7] W.R. King and D.I. Cleland, Strategic Planning and Policy (New York: Van Nostrand Reinhold, 1979); 124.

[8] Brian Dumaine, “What the Leaders of tomorrow See,” Fortune (July 3, 1989): 50.

[9] George Steiner, “Strategic Planning: What Every Manager Must Know “ (New York: The Free Press, 1979): 160.

Citation: Ph.D. Branislav Djordjevic, "The Business Vision and Mission" International Journal of Managerial Studies and Research (IJMSR), vol 9, no. 5, 2021, pp. 12-18. doi: https://doi.org/10.20431/23490349.0905002.

Copyright: (C) 2021 Authors. This is an open-access article distributed under the terms of the Creative Commons Attribution License, which permits unrestricted use, distribution, and reproduction in any medium, provided the original author and source are credited. 